\title{
CUSTOMER LOYALTY TO A GROCERY RETAILER: DIFFERENCES BETWEEN URBAN AND RURAL AREAS OF LITHUANIA
}

\author{
Lina Pilelienè, Kristina Zikienè \\ Vytautas Magnus University, Lithuania \\ lina.pileliene@vdu.lt; kristina.zikiene@vdu.lt
}

\begin{abstract}
Given the intensive competition in almost all the business sectors, customer loyalty research is gaining its popularity among marketers as well as among scholars. The aim of this research was to determine the differences in loyalty to grocery retailer between urban and rural consumers. In order to reveal the differences, questionnaire research was provided and differences between Lithuanian urban and rural customer loyalties were determined. The research results indicated the existence of statistically significant differences between the loyalties of Lithuanian urban and rural regarding their mostly visited grocery retailers in terms of their attitudes and repeat patronage behaviour. Moreover, based on the neo-behaviouristic approach, considering attitudinal and behavioural measures, all kinds of loyalties were observed stronger in the urban areas of Lithuania. The assumption was made that there might be an effect of limited-choice condition. Affected by the latter condition, rural citizens tend to seek for variety more than the urban ones. Consequently, considering the rural citizens' evaluations, it can be stated that their loyalty is undermanaged, resulting in a very low amounts of truly loyal customers. Therefore, for the grocery retailers it was recommended to revise their customer loyalty schemes based on the point of residence of their consumers. In such a way the higher possibility of meeting consumer needs might be achieved.
\end{abstract}

Key words: attitudinal loyalty, behavioural loyalty, customer loyalty, grocery retailer, Lithuania.

\section{Introduction}

Modern competitive business environment makes it more and more difficult to gain and retain competitive advantage. Gaining and retaining customer loyalty is considered to be one of the crucial goals for companies that lead to successful competition in everchanging business word. The customer has become the central focus for most companies (Makanyeza, 2015; Boohene \& Agayapong, 2011). It is becoming a regular assessment of successful businesses to place customer loyalty at the centre of their marketing strategy. Different authors acknowledge benefits of long-term customer relationship and loyalty for the companies (O’Malley, 1998; Nordman, 2004; Rust \& Oliver, 1994; Reinartz \& Kumar, 2000). The following arguments are suggested: decline of customer retention rates by several per cents determines significant decrease in profitability of the company (Reichheld \& Sasser, 1990); attraction of new customers costs much more for the company than retention of the existent ones, and customer loyalty increases growth potential of the company (Hesket, 2002; Nordman, 2004). Loyal customers purchase significantly more products / services 'related' to the main product or service (Little \& Marandi, 2003) and contribute to the reduction of marketing costs (Nordman, 2004). Costs of loyal customer service are lower, companies receive price premiums as loyal customers are less sensitive to prices, and word-of-mouth by loyal customers reduces costs of new customer acquisition (Nordman, 2004; Černiauskienè \& Stankevičienè, 2007).

Marketing theory gives a high emphasis on customer loyalty construct. However, the antecedents, participating in the formation of customer loyalty, have generated a lot of discussion and debate. Analysing the process of customer loyalty formation, researchers mention different tools for loyalty building; distinguish various factors, affecting customer loyalty formation. Special attention in today's rapidly changing business environment attracts some nonessential factors influencing relationships between organizations and customers such as market structure or insufficient number of available alternatives, which can serve as a limitation for customer switching behaviour, and it is particularly likely that if customers do not notice or other alternatives simply do not exist in the market, they will tend to continue relationship with the current organization (Storbacka, Strandvik, \& Grönroos, 1994; Bendapudi \& Berry, 1997; Colgate \& Lang, 2001). According to the market structure or insufficient number of available alternatives, as an antecedent in customer loyalty formation process, different areas in counties - mostly urban and rural, can generate different amount of loyal customers, just because of the customers' ability to have greater variety of choices. Dick \& Basu (1994) argue that even formation of different loyalty categories (according to Dick \& Basu (1994) model) is dependent on customers' opportunity to have sufficient number of available alternatives. According to these theoretical insights, it could be stated that people, living in rural places, tend to be more loyal than those living in urban, just because of market structure or insufficient number of available alternatives.

Little research has been done about customers' loyalty differences between rural and urban areas in grocery retailing, though research shows that the biggest interest in loyalty formation in retail sector is in the grocery retailing (Ott, 2011). Authors of this article have chosen to analyse Lithuanian grocery 
retailing, because grocery retailers act in fast moving consumer goods (FMCG) sector, where competition is very high, many customers use grocery retailers' loyalty cards, and even rural areas of the country have at least one grocery retailer.

Research problem in this article is formulated as a question: what are the differences in customer loyalty to grocery retailer between urban and rural areas of Lithuania?

The aim of the paper is to determine the differences in loyalty to grocery retailer between urban and rural consumers.

In order to reach the aim of the article, questionnaire research will be provided.

The paper consists of both theoretical and empirical analysis. After the presentation of theoretical insights, research methodology is outlined, following with research findings. Finally, conclusions are stated.

\section{Materials and Methods}

Loyalty construct. Customer loyalty construct is as an integral part of consumer behaviour theory and has evolved over the years (Boohene \& Agayapong, 2011; Makanyeza, 2015). Having much attention in both academic and business word, nowadays customer loyalty focuses on brands, stores, services and activities (Makanyeza, 2015). The concept of customer loyalty has changed over the decades, too. Previous research on the conception of relationship marketing (see Zikiene \& Pileliene, 2011) enabled to distinguish two basic customer loyalty conceptions: behaviouristic and neo-behaviouristic. The behaviouristic customer loyalty conception dominated in the sixth decade of the twentieth century; the basic idea of the concept was that customer loyalty is reflected by permanent purchases of the same brand or at the same pointof-purchase (Zikiene \& Pileliene, 2011). Yim \& Kannan (1999), emphasizing behaviouristic approach mention an exclusive or a hard-core loyal customer; hard-core loyal consumers are loyal to a single alternative despite many choice possibilities. The topic of identity between repeat purchases and customer loyalty was considered early. Cunningham in 1956 based on empiric research identified factors affecting purchase behaviour; latter factors were not considered by the behaviouristic loyalty conception (Zikienè \& Prèskienè, 2013). The neo-behaviouristic customer loyalty conception is based on Day's (1969) conceptual attitude that customer loyalty is a twodimensional construct, accordingly, both aspects have to be considered. Day's customer loyalty conception encompassing behavioural and attitudinal measures is applicable till nowadays. Many authors (Jacoby \& Kyner, 1973; Jacoby \& Chesnut, 1978; Backman \& Crompton, 1991; Pritchard, Havitz, \& Howard, 1999; et al.) provide their own modifications of the concept; however, the modifications do not vary much from Day's (1969) conception. The most widely analysed neo-behaviouristic conception of customer loyalty can be found at Dick \& Basu's (1994) scientific researches (Zikienè \& Prèskienè, 2013). According to the neobehaviouristic customer loyalty conception, customer loyalty is expressed by:

1. Behavioural loyalty, which is reflected by actual amount of product/services purchases in a concrete period of time;

2. Attitudinal loyalty, which is represented by preferences for a certain brand's product or service, satisfaction with a product or a service, commitment, the likelihood of repeat purchase, advocacy activities (positive word-of-mouth, recommendations).

Despite the scientific opinion about appropriateness of the behaviouristic loyalty conception, the authors of this article accept a neo-behaviouristic approach; both, attitudinal and behavioural measures have to be considered while measuring customer loyalty.

The neo-behaviouristic customer loyalty conception is based on identification of customer loyalty categories. Dick \& Basu (1994) define customer loyalty as a combination of repeat patronage and object-related attitude. Accordingly, four categories of customer loyalty can be identified:

1. True loyalty, expressed by positive reviews and attitude (attitudinal loyalty), and repeat purchases (behavioural loyalty);

2. Latent loyalty, related to positive attitude (attitudinal loyalty), but not to repeat purchases (behavioural loyalty);

3. Spurious loyalty, expressed by a low level of positive reviews (attitudinal loyalty), but huge repeat purchases (behavioural loyalty);

4. No loyalty, expressed by a low level of positive reviews (attitudinal loyalty) and a low level of repeat purchases (behavioural loyalty).

Based on the two-dimensional construct of customer loyalty, Dick \& Basu determined four levels of loyalty. They are illustrated in Figure 1.

It is acknowledged that consumers representing true loyalty have strong attitudes and high repeat purchase intentions toward a product or brand. In most situations these customers purchase a particular brand or encourage a particular service provider (Makanyeza, 2015). In true loyalty, a conscious decision to continue purchasing a particular product or from particular provider must be accompanied by the positive attitude and commitment toward that product (Boohene \& Agyapong, 2011).

Latent loyalty is characterized by strong attitudinal commitment and low purchase behaviour. O'Malley (1998) points out that this is most likely a result of situational influences - including inconvenient store 


\begin{tabular}{ll|l|l|}
\multicolumn{2}{c}{} & \multicolumn{2}{c}{ Behaviour (Repeat Patronage) } \\
\cline { 3 - 4 } $\begin{array}{ll}\text { Relative } \\
\text { attitude }\end{array}$ & High & True Loyalty & Latent Loyalty \\
\cline { 3 - 4 } & Low & Spurious Loyalty & No Loyalty \\
\hline
\end{tabular}

Source: Dick and Basu (1994).

Figure 1. Four levels of customer loyalty.

locations, out-of-stock situations, and/or the influence of other people. In the situations of latent loyalty, Dick \& Basu (1994) remark that managerial efforts are best focused on removing the interferences to patronage, for example, by extending the branch network.

Customers representing spurious loyalty are not emotionally attached to the brand or product even though they may frequently purchase it. In such situations, repeat purchase may be based on the availability of deals, special offers, convenience or inconvenience or the influence of other people (O’Malley, 1998; Schiffman \& Kanuk, 2004; Makanyeza, 2015). Schiffman \& Kanuk (2004) suggest that consumers representing spurious loyalty can continue to purchase products or brands even they really may not like them (Makanyeza, 2015). By the way, Assael (2004) confirms that an uncommitted customer may continue shopping in a particular store because he/she does not have enough time and it is easier to shop in one place. This indicates inertia rather than true loyalty. According to these insights, the authors of this study emphasize that normally rural areas have a smaller number of grocery retailers than urban areas, so it can serve as a limitation for customer switching behaviour and tend to continue relationship with the current grocery retailer.

Customers with low loyalty represent no loyalty at all. Their attitudinal loyalty is low as well as their behaviour is not accompanied by any repeat purchases. According to O'Malley (1998), no loyalty situations are common in markets where the product has low rates of differentiation, and its selling strategy is not supported by any sales promotion or loyalty building program.

Loyalty measurement. Customers may express their loyalty in many different ways, reflecting their attitudes of resulting in purchase patterns. It is recognised that segmenting loyal customers can assist in developing an understanding of the nature of loyalty orientation and can inform appropriate marketing actions (Rowley, 2005). Previous research (Bakanauskas \& Pilelienè, 2008; Pilelienè, 2010) enabled the elaboration of the model for the determination loyalty stages; moreover, it was concluded that different managerial actions have to be taken based on the state of customer loyalty. However, the scientific literature mostly provides Dick \& Basu's (1994) model of loyalty assessment and segmentation. The authors argue that loyalty is determined by the strength of the relationship between relative attitude and repeat patronage, and that it has both attitudinal and behavioural elements.

Based on the two-dimensional construct of customer loyalty, Dick and Basu determined four levels of loyalty (true, latent, spurious and low (no) loyalty) as already explained. The behavioural loyalty leads the customer to repeat purchases. It denotes a brand or product preference over time. The attitudinal loyalty explains the customer's intention to purchase again and to recommend the product to others (Kandampully \& Suhartanto, 2000, Makanyeza, 2015). To conclude, customer loyalty is to be measured in the context of attitudinal and behavioural loyalty. These approaches are not contradictory, but complementary. Different customers have different attitude, leading to differences in behaviour. Accordingly, organizations focus to customer loyalty must be aligned with customer loyalty categories.

Questionnaire design. The design of the questionnaire was established to reflect the two dimensions of customer loyalty (latent variables): 'relative attitude' and 'repeat purchase behaviour'. Ten manifest variables (five items for the attitudinal, and five items for the behavioural components) were used to assess customer loyalty based on previous researches by Makanyeza (2015), Lewis \& Soureli (2006), Söderlund (2006). Table 1 illustrates the items used to measure customer loyalty; each item was given a code. Respondents were asked to provide their evaluations of agreement or disagreement with the statements based on a 5-point Likert scale that ranged from 1 'strongly disagree' to 5 'strong agree'.

The questionnaire survey was provided in Lithuania in December 2016. The total sample was 350 respondents (209 female); 175 respondents (94 female) were rural and 175 respondents (115 female) 
Items used to measure customer loyalty

Table 1

\begin{tabular}{|l|c|}
\hline & Code \\
\hline The shopping centre I used to shop is good & ATT1 \\
\hline The shopping centre I used to shop ensures a high quality of products & ATT2 \\
\hline The shopping centre I used to shop is my favourite & ATT3 \\
\hline The shopping centre I used to shop is welcoming & ATT4 \\
\hline I trust the shopping centre I used to shop & ATT5 \\
\hline Next time I will go back shopping to this shopping centre & BEH1 \\
\hline Mostly I just do my shopping in this shopping centre & BEH2 \\
\hline I spend the most money doing my shopping in this shopping centre & BEH3 \\
\hline I have a positive contribution and recommend this shopping centre to my relatives and friends & BEH4 \\
\hline $\begin{array}{l}\text { When I have other alternatives to do my shopping rather the usual shopping centre, anyway I choose } \\
\text { to do my shopping in the usual one }\end{array}$ & BEH5 \\
\hline
\end{tabular}

Source: adapted from Makanyeza (2015); Lewis and Soureli (2006); Söderlund (2006).

were urban citizens. All the respondents were over 18 years old.

Data distribution was tested using the KolmogorovSmirnov Test and the Shapiro-Wilk Test and reliability analysis were performed to substantiate the suitability of data for further analysis. The $\mathrm{p}$ values of all the results were below 0.05 , meaning that data were not distributed normally. The Cronbach's Alphas were obtained 0.798 for the construct 'relative attitude' and 0.771 for the construct 'repeat purchase behaviour'.

\section{Results and Discussion}

In order to analyse the differences between loyalty of urban and rural customers, the evaluation means for each latent variable ('relative attitude' and 'repeat purchase behaviour') were calculated. As the evaluation of manifest variables (five to reflect each manifest variable) was provided in 5-point Likert scale, where ' 1 ' indicates absolute disagreement with the statement, and ' 5 ' - total agreement with the statement, the breaking point was decided to be ' 4 '. The evaluation ' 4 ' means that the respondent agrees with the statement; however, his / her opinion is not extremely strong. Therefore, all the evaluation means which were obtained below ' 4 ' were considered as indicating low attitude or intended behaviour. Similarly, all the evaluation means of ' 4 ' and higher were considered as indicating high respondent's attitude to the grocery retailer or intended behaviour in terms of future purchases. After calculating the means of evaluations, respondents were divided into four categories, based on the Dick's and Basu's (1994) classification. Respondent distribution according to the level of their loyalty is provided in Figure 2.

As it can be seen in Figure 2, the evaluation differences between urban and rural customers are

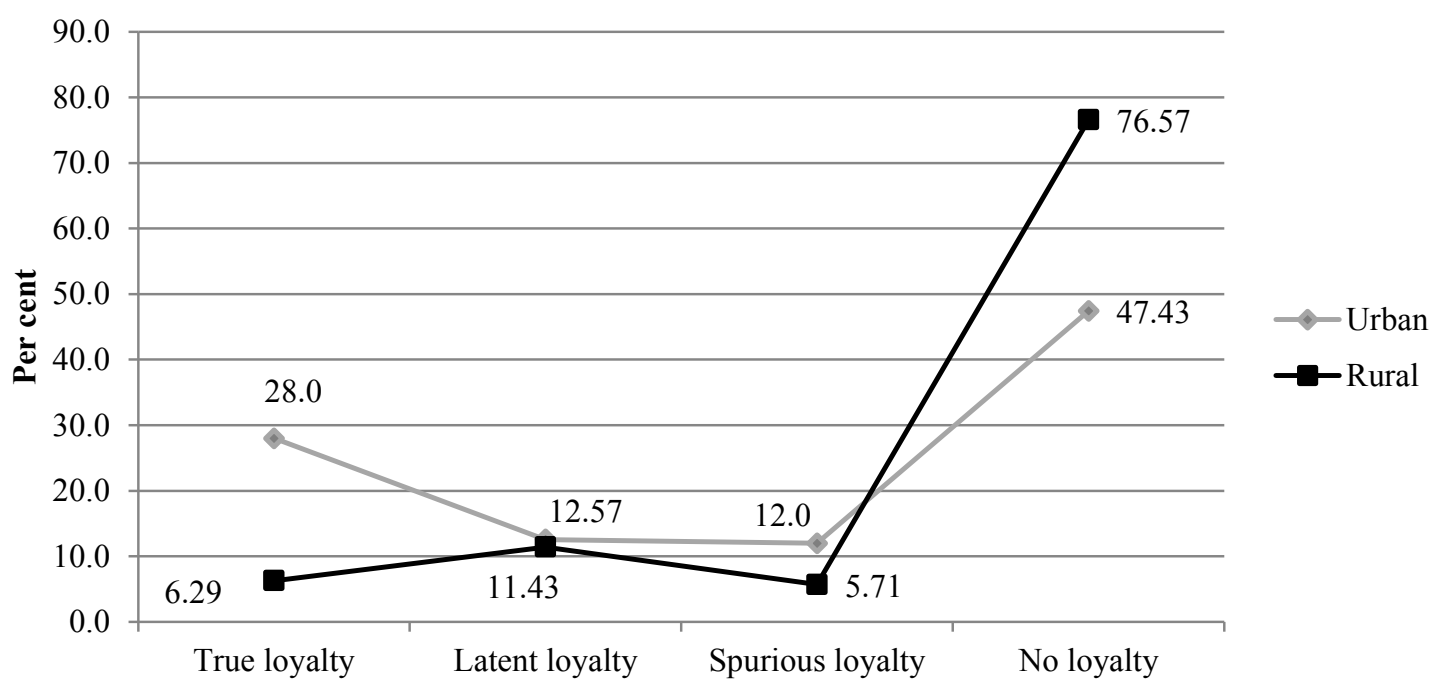

Figure 2. The levels of Lithuania customer loyalty to grocery retailers, $\mathrm{N}=350$. 
Table 2

Differences between urban and rural customer attitudinal loyalty to grocery retailers in Lithuania

\begin{tabular}{|l|l|l|l|l|l|l|}
\hline Parameter & ATT1 & ATT2 & ATT3 & ATT4 & ATT5 \\
\hline Urban citizens & Mean & 4.08 & 3.83 & 3.53 & 3.85 & 3.79 \\
\hline Rural citizens & Mean & 3.62 & 3.09 & 2.84 & 3.39 & 3.35 \\
\hline Total & Mean & 3.85 & 3.46 & 3.18 & 3.62 & 3.57 \\
\hline Mann-Whitney U & 11244.000 & 8777.500 & 9670.500 & 11839.000 & 11904.500 \\
\hline Wilcoxon W & 26644.000 & 24177.500 & 25070.500 & 27239.000 & 27304.500 \\
\hline Z & -4.991 & -7.581 & -6.180 & -4.127 & -3.993 \\
\hline Asymp. Sig. (2-tailed) & .000 & .000 & .000 & .000 & .000 \\
\hline
\end{tabular}

obvious. The smallest difference was obtained in the category 'Latent loyalty'; however in the extremes differences are enormous. The results indicate that customer loyalty to a grocery retailer is much higher in urban areas of a country even though 47.43 per cent of urban respondents' were described as having 'no loyalty' to their regularly visited shopping centre. The category of non-loyal customers among rural citizens was also the largest one - it comprised more than three-quarters of rural respondents. Moreover, only 6.29 per cent of rural respondents were attached to the category of 'true loyalists'. Latter results indicate the necessity of customer loyalty and relationship management in Lithuania, primarily in rural country areas.

However, if considering customers which were attached to the categories of 'latent loyalty' and 'spurious loyalty' as loyal, the situation in the urban areas of Lithuania can be called satisfactory. Even 28 per cent of urban respondents exhibited 'true loyalty', 12.57 per cent - 'latent loyalty', and 12 per cent 'spurious loyalty'. Altogether somehow loyal customers comprised 52.57 per cent of the sample.

The determined differences in the structure of customer loyalty to a grocery retailer between urban and rural citizens imply that different loyaltyrelated aspects have to be managed in particular areas. Therefore, it is necessary to determine the undermanaged aspects; moreover, it is necessary to determine the area-specific undermanaged aspects.

Achieving to determine the main differences between urban and rural citizen evaluations, means were calculated for each statement of the questionnaire in three ways: statement's evaluation mean by rural respondents, statement's evaluation mean by urban respondents and statement's general evaluation mean. Also, mean differences between the evaluations provided by urban and rural citizens were calculated and Mann-Whitney U test was applied to determine the statistically significant differences between evaluations.

The analysis of the research results indicates that there are evident statistically significant differences between urban and rural customer attitudinal loyalty to a grocery retailer - the evaluation means were found to be statistically significantly different for all the five evaluated statements. The research results indicate that urban customers are statistically significantly more loyal that the rural ones (see Table 2).

All the evaluation means reflecting general evaluations means as well as urban customers' evaluations were obtained above ' 3 '. In a 5-point Likert scale ' 3 ' is often a breaking point, indicating indifference or a lack of opinion. Therefore, all the evaluations above ' 3 ' are considered as being positive. Moreover, the mean of evaluations provided by urban customers for a statement that the shopping centre was good were obtained above '4'; such a high evaluation mean indicates that customers are satisfied with their regular shopping centre. Analysing the results provided by the rural respondents, the situation changes. The statement ATT3 indicating that the shopping centre was respondent's favourite was evaluated negatively - the evaluation mean was obtained below ' 3 '. The negative evaluation of the statement indicates the low consumer choice possibility. The lack of shopping centres in rural area creates the situation when consumers are choosing the closest, not the preferred one even though all the other attitudinal aspects were evaluated positively by rural customers, indicating quite high quality standards in an industry of grocery retailing in Lithuania.

During the further analysis of the research results, the evaluations of behavioural loyalty reflecting statements were analysed. All the evaluation means were found to be statistically significantly different for all the five evaluated statements as it was for attitudinal loyalty reflecting statements (see Table 3 ).

As it can be observed in Table 3, all the general evaluation means for each statement were obtained positive (in a range between ' 3 ' and ' 4 '). Therefore, it can be argued that general situation can be considered as positive in terms of customer behavioural loyalty. However, the mean differences between urban and rural respondents' evaluations indicate the lack of behavioural loyalty in rural areas. The situation is 
Differences between urban and rural customer behavioural loyalty to grocery retailers in Lithuania

\begin{tabular}{|l|l|l|l|l|l|l|}
\hline Parameter & BEH1 & BEH2 & BEH3 & BEH4 & BEH5 \\
\hline Urban citizens & Mean & 4.04 & 3.72 & 3.78 & 3.51 & 3.40 \\
\hline Rural citizens & Mean & 3.46 & 3.33 & 3.25 & 3.07 & 2.90 \\
\hline Total & Mean & 3.75 & 3.53 & 3.51 & 3.29 & 3.15 \\
\hline Mann-Whitney U & 10189.500 & 11837.000 & 10799.000 & 11404.500 & 11101.500 \\
\hline Wilcoxon W & 25589.500 & 27237.000 & 26199.000 & 26804.500 & 26501.500 \\
\hline Z & -5.906 & -3.997 & -5.003 & -4.350 & -4.635 \\
\hline Asymp. Sig. (2-tailed) & .000 & .000 & .000 & .000 & .000 \\
\hline
\end{tabular}

best described by the negative evaluation of the statement that in case of a choice, a consumer will choose the usual shopping centre - the statement's evaluation mean was obtained 2.90 meaning that rural consumers are variety seeking, regardless of the positive evaluations of centre's quality. Moreover, the statement reflecting consumers' intentions to recommend the shopping centre to their relatives and friends was evaluated very low by rural respondents; the evaluation mean was obtained 3.07. Despite being evaluated above ' 3 ', consumer recommendations are often considered as one of the principal indicators of customer loyalty; therefore, the statement's evaluation can be considered as negative.

\section{Conclusions}

In the conditions of tough competition, loyal consumers can be considered as a valuable asset of any company. Therefore, customer loyalty assessment is a field of discussions not only for managers, but for scientists as well. During the century of the evolution of marketing thought, many typologies of customer loyalty have been elaborated. However, many of them have been based on the neo-behaviouristic approach, incorporating both: attitudinal and behavioural measures.
The business of grocery retailing is one the most overcrowded industries, where keeping loyal customers is vital. However, the customer relationship situation in this industry is different depending on the area: rural or urban. In rural areas consumer choice is often limited because of smaller number of alternatives. Therefore, the competition among grocery retailers in rural area is mellower. Having limited choice possibilities, rural consumers often visit the same (often closest) shopping centre. However, calling such a forced shopping behaviour as 'loyalty' would be myopic.

The research provided with two samples of respondents (urban and rural citizens) enables the initiation of discussion on the effect of limited-choice condition on consumer loyalty. Research results indicate the existence of higher customer loyalty in urban areas of the country; namely, in those areas where customers have a free choice possibility. Considering the evaluations provided by the rural citizens, it can be stated that customer loyalty is undermanaged, resulting in a very low amounts of truly loyal customers. Therefore, for the grocery retailers it can be recommended to revise their customer loyalty schemes according to consumer point of residence.

\section{References}

1. Assael, H. (2004). Consumer behaviour: A strategic approach. Boston: Houghton Mifflin Company.

2. Backman, S.J., \& Crompton, J.L. (1991). Differentiating between high, spurious, latent and low loyalty participants in two leisure activities. Journal of park and recreation administration: A publication of the American Academy for Park and Recreation Administration. 9 (2), 1 - 17.

3. Bakanauskas, A.P., \& Pilelienè, L. (2008). Vartotojų lojalumo stadijų nustatymo modelis (Model of the determination of customer loyalty stage). Organizaciju vadyba: sisteminiai tyrimai. 48, 7 - 21. (in Lithuanian).

4. Bendapudi, N., \& Berry, L.L. (1997). Customer's motivations for maintaining relationships with service providers. Journal of Retailings. Spring. 73 (1), 15 - 38. DOI: 10.1016/S0022-4359(97)90013-0.

5. Boohene, R., \& Agyapong, G.K.Q. (2011). Analysis of the Antecedents of Customer Loyalty of Telecommunication Industry in Ghana: The Case of Vodafone (Ghana). International Business Research. 4 (1), $229-240$.

6. Černiauskienè, N., \& Stankevičiene, J. (2007). Typologisation of Loyal Clients on the Basis of the Research. Social Research, 1(9), 45 - 55. 
7. Colgate, M., \& Lang, B. (2001). Switching barriers in consumer markets: an investigation of the financial service industry. Journal of Consumer Marketing. 18 (4), 332 - 347. DOI: 10.1108/07363760110393001.

8. Dick, A.S., Basu, K. (1994). Customer Loyalty: Toward an Integrated Conceptual Framework. Journal of the Academy of Marketing Science. 22 (2), 99 - 113. DOI: 10.1177/0092070394222001.

9. Heskett, J.L. (2002). Beyond customer loyalty. Managing Service Quality. 12 (6), 355 - 357. DOI: $10.1108 / 09604520210451830$.

10. Jacoby, J., \& Chestnut, R. (1978). Brand Loyalty: Measurement and Management. John Wiley \& Sons, New York, NY.

11. Jacoby, J., \& Kyner, D.B. (1973). Brand Loyalty Vs. Repeat Purchasing Behavior. Journal of Marketing Research. 10 (1), $1-9$.

12. Kandampully, J., Suhartanto, D. (2000). Customer loyalty in the hotel industry: the role of customer satisfaction and image. International Journal of Contemporary Hospitality Management. 12(6), 346 - 351. DOI: $10.1108 / 09596110010342559$.

13. Little, E., \& Marandi, E. (2003). Relationship Marketing Management. Thomson.

14. Makanyeza, Ch. (2015). An Assessment of Reliability and Validity of the Attitudinal and Behavioural Typology of Customer Loyalty in a Developing Country: Evidence from Zimbabwe. Mediterranean Journal of Social Sciences. 6 (1) S1. DOI: 10.5901/mjss.2015.v6n1s1p310.

15. Nordman, Ch. (2004). Understanding Customer Loyalty and Disloyalty - The Effect Of Loyalty Supporting - And Repressing Factors. Doctoral Dissertation, Swedish School of Economics and Business Administration, Helsingfors.

16. O’Malley, L. (1998). Can Loyalty Schemes Really Build Loyalty? Marketing Intelligence \& Planning. 16 $(1), 47-55$.

17. Ott, B. (2011). Making loyalty programs work. Business journal, October 10. Retrieved January 21, 2017, from: http://www.gallup.com/businessjournal/149570/Making-Loyalty-Programs-Work. aspx?version=print.

18. Pilelienè, L. (2010) Determination of Combinations of the Attributes of Sales Promotion for Different Loyalty Stages' Customers. Management theory and studies for rural business and infrastructure development. 20 (1), $115-122$.

19. Pritchard, M.P., Havitz, M.E., \& Howard, D.R. (1999). Analyzing the commitment-loyalty link in service contexts. Journal of the Academy of Marketing Science. 27 (3). DOI: 10.1177/0092070399273004.

20. Reichheld, F.F., \& Sasser, W.E.Jr. (1990). Zero defections: quality comes to services. Harvard Business Review. 68 (September-October), $105-111$.

21. Reinartz, W., \& Kumar, V. (2000). On the Profitability of Long-Life Customers in a Noncontractual Setting: An Empirical Investigation and Implications for Marketing. Journal of Marketing. 64 (October), 17 - 35.

22. Rowley, J. (2005). The four Cs of customer loyalty. Marketing Intelligence \& Planning. 23 (6), 574 - 581. DOI: $10.1108 / 02634500510624138$.

23. Rust, R.T., \& Oliver, R.L. (1994). Service quality: insights and managerial implications from the frontier. In Rust, R.T., \& Oliver, R.L. (Eds), Service quality: New directions in theory and practice (pp. $241-68$ ).

24. Schiffman, L.G., \& Kanuk, L.L. (2004). Consumer behaviour, 8th ed. Upper Saddle River, New Jersey: Pearson Prentice Hall.

25. Söderlund, M. (2006). Measuring customer loyalty with multi-item scales. A case for caution. International Journal of Service Industry Management. 17(1), 76 - 98. DOI: 10.1108/09564230610651598.

26. Storbacka, K., Strandvik, T., \& Grönroos, C. (1994). Managing Customer Relationships for Profit: The Dynamics of Relationship Quality. International Journal of Service Industry Management. 5 (5). DOI: 10.1108/09564239410074358.

27. Yim, C.K., \& Kannan, P.K. (1999). Consumer Behavioral Loyalty: A Segmentation Model and Analysis. Journal of Business Research. 44 (2), 75 - 92. DOI: 10.1016/S0148-2963(97)00243-9.

28. Zikienè, K., \& Pilelienè, L. (2011). Testing of methods for customer loyalty measurement in pharmacy 'Camelia'. Organizaciju vadyba: sisteminiai tyrimai. 59, 149 - 166.

29. Zikienè, K., \& Prèskienè, K. (2013). The assessment of customer loyalty programs in Lithuanian pharmacies network in the aspect of gained value. Management horizons in changing economic environment: visions and challenges: proceedings of the 12th International Scientific Conference, 26 - 28 September, 2013 (pp. 995 - 1004). Kaunas: Vytauto Didžiojo universitetas. 